DOI: 10.38136/jgon.760133

\title{
Birinci Trimester Taramasında Bakılan Serum Belirteçlerinden serbest $\beta$-hCG ve PAPP-A'nın Kötü Obstetrik Sonuçları Öngörmede Etkisi: 889 Tekil Gebelik ile yapılan Prospektif Bir Çalışma \\ Prediction of Adverse Obstetric Outcomes by First Trimester Screening with Free $\beta$-hCG and PAPP-A: A Prospective Study of 889 Singleton Pregnancies
}

\author{
Șule YILDIZ \\ Ümit Yasemin SERT \\ Esra BILIR \\ Engin TÜRKGELDi \\ Tuncay NAS
}

(1) Orcid ID:0000-0002-4803-7043
(1) Orcid ID:0000-0003-0862-4793
(1) Orcid ID:0000-0003-4499-6543
(1) Orcid ID:0000-0002-5008-3292
(1) Orcid ID:0000-0002- $6046-7249$

\footnotetext{
${ }^{1}$ Department of Obstetrics and Gynecology, Koc University Hospital, Istanbul, Turkey

2 Department of Obstetrics and Gynecology, University of Health Science, Bilkent City Hospital, Ankara, Turkey

${ }^{3}$ Koc University, School of Medicine, Istanbul, Turkey

${ }^{4}$ Department of Obstetrics and Gynecology, Gazi University Faculty of Medicine, Ankara, Turkey
}

\section{öz}

Amaç: Bu çalışmada birinci trimester tarama testinde değerlendirilen serum belirteçlerinden PAPP-A ve serbest $\beta$-hCG nin preterm eylem, preterm doğum, gestasyonel diyabetes mellitus (GDM), gebelik hipertansiyonu, preeklampsi, düşük doğum ağırığı (DDA), gebelik yaşına göre küçük (SGA), gebelik yaşına göre büyük (LGA), intrauterin gelişme geriliği (IUGR), makrozomi, intrauterin eksitus (IUEX) gibi gebelik komplikasyonları ile ilişkisini değerlendirmeyi amaçladık.

Gereçler ve Yöntem: Bu prospektif çalışma 1 Mayıs 2011 ile 1 Mayıs 2012 arasında Gazi Üniversitesi Tıp Fakültesi Hastanesi'nde yürütülmüştür. Tekil gebelik nedeni ile takip edilen ve 11-14. haftalarda birinci trimester tarama testi yapılmış 889 kadın çalışmaya dahil edilmiştir.

Bulgular: Çalışmaya kriterlere uygun olan 889 kadın dahil edildi. Yaş ortanca değeri 29 (26-33) olup serbest $\beta$-hCG MoM ve PAPP-A MoM ortanca değerleri sırasıyla $1.0(0.7-1.48)$ ve $1.04(0.73-1.46)$ idi. En sık gözlenen gebelik komplikasyonları preterm eylem 164 (18.4\%), düşük tehdidi 95 (10.7\%), ve GDM 75 (8.4\%) idi. PAPP-A MoM ile SGA, DDA ve preterm doğum arasında doğrusal bir ilişki izlendi (sırasıyla, $p<0.01$, $p=0.033$ ve $p=0.03$ ). PAPP-A MoM değerleri $\leq 0.42$ (5. persentil) $>2.5$ (95. persentil), ve 0.73-1.47 (25.-75. persentil) olmak üzere üç kategoriye ayrıldığında bu üç grup arasında SGA $(p<0.01), D D A(p=0.01)$, IUEX $(p=0.00005)$, preterm eylem $(p=0.002)$, ve IUGR $(p=0.006)$ için anlaml farkllık izlendi. Sadece preterm eylem ile serbest $\beta$-hCG MoM değerleri arasında doğrusal bir ilişki izlendi ( $p=0.007$ ). Ancak bu ilişki $\beta$-hCG MoM değerleri $\leq 0.40$ (5. persentil), >2.9 (95. persentil), ve 0.75-1.49 (25. 75. persentil) olmak üzere üç grupta kategorize edildiğinde kayboldu $(p=0.47)$. Doğum ağırlı̆ı ve PAPP-A MoM değerleri arasında göz ardı edilebilir düzeyde düşük bir korelasyon izlendi $(r=0.133, p=0.0001)$.

Sonuç: Bu çalışma birinci trimesterde bakılan serum biyokimyasal belirteçlerinden serbest $\beta$-hCG ve PAPP-A değerlerinin bazı olumsuz gebelik komplikasyonlarını öngörmede faydalı olabileceğini göstermektedir.

Anahtar Kelimeler: Birinci trimester, biyobelirteçler, $\beta$-hCG, PAPP-A, gebelik komplikasyonları

Sorumlu Yazar/ Corresponding Author:

Şule Yıldız, M.D.

Koç University Hospital, Maltepe Mahallesi, Topkapı Cd. No:4, 34010 Zeytinburnu/Istanbul, Turkey E-mail: yildizsuledr@gmail.com

Jinekoloji - Obstetrik ve Neonatoloji Tıp Dergisi 2020; Volume 17, Sayı 4,Sayfa: 497-503

\section{ABSTRACT}

Aim: We aimed to identify the association of first-trimester screening biomarkers (PAPP-A and free $\beta-h C G$ ) that correspond specific percentile with adverse pregnancy outcomes, including preterm labor, preterm delivery, gestational diabetes mellitus (GDM), gestational hypertension, preeclampsia, low birth weight (LBW), small for gestational age (SGA), large for gestational age (LGA), intrauterine growth restriction (IUGR), macrosomia, and intrauterine exitus (IUEX).

Materials and Method: This prospective study was conducted between 1st May 2011 and 1st May 2012 at Gazi University Faculty of Medicine, Turkey. We recruited only singleton pregnancies. The first-trimester screening test was performed between 11-14 weeks of gestation.

Results: Eight hundred eighty-nine of them met the inclusion criteria for our study. The median age was 29 (26-33) years. Median free $\beta$-hCG MoM and PAPP-A MoM were 1.0 (0.7 - 1.48) and 1.04 (0.73 - 1.46), respectively. The most common adverse obstetric outcomes were preterm labor 164 (18.4\%), threatened abortion 95 (10.7\%), and GDM 75 (8.4\%). There was a linear trend with PAPP-A MoM and SGA, LBW, preterm delivery $(p<0.01, p=0.033$, and $p=0.03$, respectively). When PAPP-A MoM results were categorized under three groups as $\leq 0.42$ (5th percentile), $>2.5$ (95th percentile), and 0.73-1.47 (25th -75th), a significant difference between there groups were detected for SGA $(p<0.01)$, LBW $(p=0.01)$, IUEX ( $p=0.00005)$, preterm labor $(p=0.002)$, and IUGR $(p=0.006)$. Only preterm labor showed a significant linear trend for $\beta$-hCG MoM values ( $p$ $=0.007$ ). However, this significance was not detected when $\beta$-hCG MoM values were categorized as $\leq 0.40$ (5th percentile), >2.9 (95th percentile), and $0.75-1.49$ (25th -75 th $)(p=0.47)$. The correlation coefficient of birth weight and PAPP-A MoM was 0.133 , which is negligible ( $r=0.133$, $p=0.0001$ )

Conclusion: Our study suggested the possibility of predicting the women with the risk of adverse obstetric outcomes by using first-trimester screening biomarkers, namely maternal free $\beta$-hCG, and PAPP-A levels. Key words: first trimester, biomarkers, $\beta$-hCG, PAPP-A, pregnancy complications

Başvuru tarihi : 09.07.2020 Kabul tarihi : 09.11.2020 


\section{INTRODUCTION}

The first-trimester screening test offers a noninvasive assessment for the risk of Patau syndrome (Trisomy 13), Edwards syndrome (Trisomy 18), and Down Syndrome (Trisomy 21). The first-trimester screening test performed between 11-14 weeks of gestation includes the combination of maternal serum beta-human chorionic gonadotropin ( $\beta$-hCG), pregnancy-associated plasma protein-A (PAPP-A), and fetal nuchal translucency thickness (FNTT). The correlation between several first trimester biomarkers and the perinatal outcome became one of the essential cornerstones of perinatal research (1). First-trimester screening is the most commonly performed test in the early gestation of pregnancy to detect aneuploidy (1). Recent studies also have demonstrated that this multi-parametric test could be used to predict several obstetric complications such as preterm birth, gestational diabetes (GDM), preeclampsia, fetal growth restriction, and macrosomia (1-5). Lower serum PAPP-A and $\beta$-hCG levels were found to be associated with more frequent obstetric complications (6-9)

The placental syncytiotrophoblast produces PAPP-A which has an essential role in invasion and fetal-placental growth (10). PAPP-A is a protease for insulin-like growth factor (IGF) binding proteins, which play a critical role in invasion and vascular development of placenta (11). Defects on the formation of the placental bed are known to be responsible for obstetric complications, including miscarriage, intrauterine exitus (IUEX), intrauterine growth restriction (IUGR), maternal hypertensive disorders, and preterm delivery. Several studies showed an association between decreased level of PAPP-A and placental dysfunction $(12,13)$. It has been postulated that low PAPP-A levels might be an indicator of abnormal placentation, thus, related to poor pregnancy outcomes. During the pregnancy, chorionic villus excretes the hormone called $\beta$-hCG, which stimulates progesterone from corpus luteum (14). Various studies evaluated the predictive value of first-trimester maternal serum $\beta$-hCG for obstetric complications such as abortion, maternal hypertensive disorders, IUGR, and gestational diabetes mellitus (GDM) (15). Although there are conflicting data on the predictive value of these biomarkers, the opportunity of predicting these adverse outcomes from the first trimester would provide the chance of taking preventive attempts to improve our current follow-up strategies $(1,15,16)$.

In this context, we aimed to identify the association of PAPP-A and free $\beta$-hCG that correspond specific percentile with adverse pregnancy outcomes. This study evaluated adverse obstetric and neonatal outcomes, namely preterm labor, preterm delivery, threatened abortion, abortion, GDM, gestational hypertension, preeclampsia, low birth weight (LBW), small for gestational age (SGA), IUGR, large for gestational age (LGA), macrosomia, oligohydramnios, polyhydramnios, and IUEX.

\section{MATERIALS AND METHOD}

This prospective study was conducted between 1st May 2011 and 1st May 2012 at Gazi University Faculty of Medicine. Our inclusion criteria were i) singleton pregnancies, ii) gestational ages between 10-week one-day and 13week six-day based on last menstrual period date, and iii) presented to our Department of Obstetrics and Gynecology for first-trimester screening. Our exclusion criteria included i) multiple pregnancies, ii) fetuses with chromosomal structural abnormalities, and iii) history of hypertension and diabetes mellitus. This study was approved by Gazi University Institutional Review Board (IRB number 99) on 27th April 2011.

We collected demographic features of pregnant women, including age, weight, and height, gravida, and parity, and calculated body mass index (BMI).
The way of conception, either spontaneous or by assisted reproductive technologies (ART), was obtained. We collected maternal serum levels of free $\beta-h C G$ and PAPP-A. The maternal serum levels of free $\beta-h C G$ and PAPP-A were detected by automated assays (IMMULITE $₫ 2000$ XPi Siemens). Prisca version 5.0 was used to calculate the risk.

All the pregnancies included in this study were regularly followed up until the delivery. Briefly, we followed up them monthly until 32 weeks of gestation, every two weeks until completed 36 weeks, and weekly until delivery. The patients, who did not regularly come to our clinic, were asked to share their results. We collected the following data for each pregnancy: gestational age at threatened abortion, abortion, preterm labor, preterm delivery, preeclampsia, eclampsia, GDM, IUGR, IUEX, gestational age at delivery, type of delivery (vaginal delivery or Cesarean delivery), and newborn's birth weight.

\section{Definitions}

Threatened abortion was used to define the bloody vaginal discharge without cervical dilation within the first 20-week pregnancy (17). Abortion was defined as the spontaneous termination of the pregnancy before 20-week gestational age (18). Preterm labor was considered before 37-week gestational age (19). The delivery of the fetus following uterine contractions with cervical dilation and effacement before 37-week gestational age was defined as preterm delivery (19). Gestational hypertension was diagnosed when blood pressure $>140 / 90 \mathrm{mmHg}$ at $\geq 20$-week gestational age in the absence of proteinuria (20). Preeclampsia was diagnosed when blood pressure $>140 / 90 \mathrm{mmHg}$ and proteinuria of $>300 \mathrm{mg}$ in 24-hour urine protein after 20-week of pregnancy (21). Each pregnant woman was screened for GDM between 24-week and 28-week gestational age. The diagnosis of GDM was made according to the American Diabetes Association criteria (22). Briefly, abnormal was defined as the serum glucose value of $<140 \mathrm{mg} / \mathrm{dL}$ one hour after a 50 -gram oral glucose load (22). Following this abnormal result, a 100-gram oral glucose load was performed, and normal serum glucose values were accepted for fasting, one hour, two hours, and three hours as $95 \mathrm{mg} / \mathrm{dL}, 180 \mathrm{mg} / \mathrm{dL}, 155 \mathrm{mg} / \mathrm{dL}$, and $140 \mathrm{mg} / \mathrm{dL}$, respectively (22). Oligohydramnios was defined as a single deepest pocket (SDP) $<2 \mathrm{~cm}$ or amniotic fluid index (AFI) $\leq 5 \mathrm{~cm}$ (23). Polyhydramnios was accepted as $\mathrm{SDP} \geq 8 \mathrm{~cm}$ and $\mathrm{AFI} \geq 24 \mathrm{~cm}$ (24).

Intrauterine growth restriction accepted as $<10$ th percentile estimated weight in the second half of the pregnancy (25). The fetal birth weight $<10$ th percentile and $>90$ th percentile for gestational age was accepted as small for gestational age (SGA) and large for gestational age (LGA), respectively $(26,27)$. The fetal birth weight $>4000$ grams was accepted as macrosomia (28). Neonatal birth weight $<2500$ grams was defined as low birth weight (LBW) (29).

\section{Statistics}

We used Statistical Package for the Social Sciences (SPSS) Version 26.0 (Chicago, IL, USA) to analyze our data. The descriptive analysis (frequency, percentage, mean, median, and percentile) was performed. Median values were presented with 25 th and 75 th percentiles for non-normally distributed data. Chi-square for linear trend was used to show a linear trend between the obstetric complications and $\beta$-hCG MoM and PAPP-A MoM values. We accepted a p-value of $\leq 0.05$ as statistically significant in the $95 \%$ confidence interval (Cl) for our study. Pearson correlation was used to calculate the correlation coefficient between birth and PAPP-A MoM.

\section{RESULTS}

We recruited 1000 women with singleton pregnancies during the study period Eight hundred eighty-nine of them met the inclusion criteria for our study. The demographic characteristics of the patients listed in Table 1. The median age 
was 29 (26-33) years. The median gravida and parity were $2(1-3)$ and $0(0-1)$, respectively. The majority of the patients did not smoke tobacco (90.9\%). Almost two percent of them quitted tobacco smoking after they were pregnant. Only $4.0 \%$ of the pregnancies were achieved by ART. The serum free $\beta-h C G$ MoM and PAPP-A MoM values and their percentile equivalent were listed in Supplementary Table 1.

Table 1: Baseline Characteristics of the Patients

\begin{tabular}{|l|l|}
\hline $\begin{array}{l}\text { Variable } \\
(\mathrm{n}=889)\end{array}$ & $\begin{array}{l}\text { Median }\left(25^{\text {th }}-75^{\text {th }} \text { percentile }\right) \\
(\mathrm{n}=889)\end{array}$ \\
\hline Age (year) & $29(26-33)$ \\
\hline Gravida & $2(1-3)$ \\
\hline Parity & $0(0-1)$ \\
\hline $\begin{array}{c}\text { Smoker (\%) } \\
-\quad \text { Yes }\end{array}$ & $67(7.5 \%)$ \\
$-\quad$ No & $808(90.9 \%)$ \\
$-\quad$ Quit after pregnancy & $14(1.6 \%)$ \\
\hline $\begin{array}{l}\text { Method of Conception } \\
-\quad \text { Spontaneous }\end{array}$ & $853(96 \%)$ \\
$-\quad$ ART & $36(4 \%)$ \\
\hline
\end{tabular}

ART: assisted reproductive technologies

The obstetrics and neonatal characteristics were presented in Table 2.

Table 2: Obstetrics and Neonatal Characteristics

\begin{tabular}{|c|c|}
\hline $\begin{array}{l}\text { Variable } \\
(\mathrm{n}=889)\end{array}$ & $\begin{array}{l}\text { Median } \\
\left(25^{\text {th }}-75^{\text {th }} \text { percentile }\right)\end{array}$ \\
\hline First trimester screening time & $\begin{array}{l}\text { 12-week and 2-day } \\
\text { (11-week and 5-day - 12- week and 5-day) }\end{array}$ \\
\hline Free $\beta$-hCG MoM & $1(0.7-1.48)$ \\
\hline PAPP-A MoM & $1.04(0.73-1.46)$ \\
\hline Complications (\%) & \\
\hline - Preterm labor & $164(18.4)$ \\
\hline - Preterm delivery & $66(7.4)$ \\
\hline - Threatened abortion & $95(10.7)$ \\
\hline - Abortion (12-20 week) & $9(1.0)$ \\
\hline - $\quad G D M$ & $75(8.4)$ \\
\hline - Gestational hypertension & $54(6.1)$ \\
\hline - Preeclampsia & $19(2.1)$ \\
\hline - LBW & $49(5.5)$ \\
\hline - $\quad S G A$ & $16(1.8)$ \\
\hline - IUGR & $13(1.5)$ \\
\hline - LGA & $11(1.2)$ \\
\hline - Macrosomia & $40(4.5)$ \\
\hline - Oligohydramnios & $24(2.7)$ \\
\hline - Polyhydramnios & $10(1.1)$ \\
\hline - IUEX & $8(0.9)$ \\
\hline Gestational Age at Delivery & $\begin{array}{l}\text { 38-week and 5-day } \\
\text { (38-week and 1-day - } 39 \text { week and 4-day) }\end{array}$ \\
\hline Route of delivery (\%) & \\
\hline - Vaginal & $334(37.6)$ \\
\hline - Cesarean Section & $555(62.4)$ \\
\hline Birth weight (grams) & $\begin{array}{l}3250 \\
(2990-3540) \\
\end{array}$ \\
\hline NICU Admission (\%) & \\
\hline Yes & $93(10.5)$ \\
\hline - Preterm birth & $32(3.6)$ \\
\hline - Hyperbilirubinemia & $29(3.3)$ \\
\hline - Others & $32(3.6)$ \\
\hline No & $796(89.5)$ \\
\hline
\end{tabular}

GDM: gestational diabetes mellitus, $\beta$-hCG: beta human chorionic gonadotropin, IUEX: intrauterine exitus, IUGR: intrauterine growth restriction, LBW: low birth weight, LGA: large for gestational age, MoM: multiple of median, NICU: neonatal intensive care unit, PAPP-A: pregnancy associated plasma protein-A, SGA: small for gestational age

The median gestational age for first-trimester screening was 12-week and 2-day (11-week and 5-day - 12- week and 5-day). Median free $\beta$-hCG MoM and PAPP-A MoM were 1.0 (0.7 - 1.48) and 1.04 (0.73 - 1.46), respectively. In total, 653 complications were detected where some patients had multiple. The most common adverse obstetric outcomes were preterm labor 164 (18.4\%), threatened abortion 95 (10.7\%), and GDM 75 (8.4\%). The median gestational age at delivery was 38-week and 5-day (38-week and 1-day 39 -week and 4-day). More than half of the patients (62.4\%) were undergone Cesarean Section. The median birth weight was 3250 grams (2990-3540). Ninety-three newborns (10.5\%) were admitted to NICU. The majority of the indications for NICU admission were neonatal complications of preterm birth $32(3.6 \%)$, and hyperbilirubinemia $29(3.3 \%)$.

There was a linear trend with PAPP-A MoM and SGA, LBW, preterm delivery $(p=<0.01,0.033$, and 0.03 , respectively) (Table 3).

Table 3: The Linear Trend between PAPP-A MoM and SGA, LBW, IUEX, Preterm Labor and Preterm Delivery

\begin{tabular}{|c|c|c|}
\hline $\begin{array}{l}\text { PAPP-A MoM } \\
\text { Percentiles }\end{array}$ & $\begin{array}{l}\text { Number of patients with complication in } \\
\text { this category }(\%)\end{array}$ & $\begin{array}{l}\mathrm{p} \text {-value } \\
\text { for linear trend }\end{array}$ \\
\hline & \multicolumn{2}{|l|}{ SGA } \\
\hline$\leq 0.26$ & $2 / 6(33.3)$ & \multirow{5}{*}{$<0.01$} \\
\hline $0.27-0.42$ & $4 / 34(11.7)$ & \\
\hline $0.43-0.52$ & $7 / 41(17.0)$ & \\
\hline $0.53-0.73$ & $3 / 28(10.7)$ & \\
\hline \multirow[t]{2}{*}{$>0.73$ (control group) } & $0 / 780(0.0)$ & \\
\hline & LBW & \\
\hline$\leq 0.26$ & $4 / 8(50.0)$ & \multirow{5}{*}{0.0333} \\
\hline $0.27-0.42$ & $2 / 34(5.8)$ & \\
\hline $0.43-0.52$ & $4 / 42(9.5)$ & \\
\hline $0.53-0.73$ & $11 / 137(8.0)$ & \\
\hline \multirow[t]{2}{*}{$>0.73$ (control group) } & $28 / 668(4.1)$ & \\
\hline & \multicolumn{2}{|l|}{ Preterm Delivery } \\
\hline$\leq 0.26$ & $1 / 6(16.6)$ & \multirow{5}{*}{0.030} \\
\hline $0.27-0.42$ & $3 / 34(8.8)$ & \\
\hline $0.43-0.52$ & $5 / 42(11.9)$ & \\
\hline $0.53-0.73$ & $15 / 137(10.9)$ & \\
\hline \multirow[t]{2}{*}{$>0.73$ (control group) } & $42 / 670(6.3)$ & \\
\hline & \multicolumn{2}{|l|}{ Preterm Labor } \\
\hline$\leq 0.26$ & $5 / 9(55.5)$ & \multirow{5}{*}{0.744} \\
\hline $0.27-0.42$ & $12 / 36(33.3)$ & \\
\hline $0.43-0.52$ & $7 / 42(16.6)$ & \\
\hline $0.53-0.73$ & $21 / 137(15.3)$ & \\
\hline$>0.73$ (control group) & $119 / 665(17.8)$ & \\
\hline \multicolumn{3}{|c|}{ IUEX } \\
\hline$\leq 0.26$ & $3 / 9(33.3)$ & \multirow{5}{*}{0.759} \\
\hline $0.27-0.42$ & $0 / 36(0.0)$ & \\
\hline $0.43-0.52$ & $1 / 43(2.3)$ & \\
\hline $0.53-0.73$ & $0 / 137(0.0)$ & \\
\hline$>0.73$ (control group) & $4 / 664(0.6)$ & \\
\hline
\end{tabular}

IUEX: intrauterine exitus, LBW: low birth weight, MoM: multiple of median, PAPP-A: pregnancy associated plasma protein-A, SGA: small for gestational age

However, preterm labor and IUEX did not show a linear trend with PAPP-A MoM. When PAPP-A MoM results were categorized under three groups as $\leq 0.42$ (5th percentile), $>2.5$ (95th percentile), and 0.73-1.47 (25th -75th), a significant difference between there groups were detected for SGA $(p<0.01)$, LBW $(p=0.01)$, IUEX $(p=0.00005)$, preterm labor $(p=0.002)$, IUGR $(p=0.006)$ (Table 4). 
Table 4: The relationship between PAPP-A MoM and SGA, LBW, IUEX, and Preterm Labor

\begin{tabular}{|c|c|c|}
\hline $\begin{array}{l}\text { PAPP-A MoM } \\
\text { Categories }\end{array}$ & $\begin{array}{l}\text { Number of patients with complication in } \\
\text { this category }(\%)\end{array}$ & $\mathrm{p}$-value \\
\hline \multicolumn{3}{|c|}{ SGA } \\
\hline$\leq 0.42\left(5^{\text {th }}\right.$ percentile $)$ & $6 / 45(13.3)$ & \multirow{3}{*}{$<0.01$} \\
\hline$>2.5\left(95^{\text {th }}\right.$ percentile $)$ & $0 / 451(0.0)$ & \\
\hline $0.73-1.47\left(25^{\text {th }}-75^{\text {th }}\right)$ & $0 / 46(0.0)$ & \\
\hline \multicolumn{3}{|c|}{ LBW } \\
\hline$\leq 0.42\left(5^{\text {th }}\right.$ percentile $)$ & $6 / 45(13.3)$ & \multirow{3}{*}{0.01} \\
\hline$>2.5\left(95^{\text {th }}\right.$ percentile $)$ & $2 / 46(4.3)$ & \\
\hline $0.73-1.47\left(25^{\text {th }}-75^{\text {th }}\right)$ & $19 / 451(4.2)$ & \\
\hline \multicolumn{3}{|c|}{ IUEX } \\
\hline$\leq 0.42\left(5^{\text {th }}\right.$ percentile $)$ & $3 / 45(6.6)$ & \multirow{3}{*}{0.00005} \\
\hline$>2.5\left(95^{\text {th }}\right.$ percentile $)$ & $0 / 46(0.0)$ & \\
\hline $0.73-1.47\left(25^{\text {th }}-75^{\text {th }}\right)$ & $3 / 451(0.6)$ & \\
\hline \multicolumn{3}{|c|}{ Preterm Labor } \\
\hline$\leq 0.42\left(5^{\text {th }}\right.$ percentile $)$ & $17 / 45(37.7)$ & \multirow{3}{*}{0.002} \\
\hline$>2.5\left(95^{\text {th }}\right.$ percentile $)$ & $8 / 46(17.3)$ & \\
\hline $0.73-1.47\left(25^{\text {th }}-75^{\text {th }}\right)$ & 78/451 (17.2) & \\
\hline \multicolumn{3}{|c|}{ IUGR } \\
\hline$\leq 0.42\left(5^{\text {th }}\right.$ percentile $)$ & $1 / 45(2.2)$ & \multirow{3}{*}{0.006} \\
\hline$>2.5\left(95^{\text {th }}\right.$ percentile $)$ & $0 / 46(0.0)$ & \\
\hline $0.73-1.47\left(25^{\text {th }}-75^{\text {th }}\right)$ & $5 / 451(1.1)$ & \\
\hline
\end{tabular}

IUEX: intrauterine exitus, IUGR: intrauterine growth restriction, LBW: low birth weight, MoM: multiple of median, PAPP-A: pregnancy associated plasma protein-A, SGA:

small for gestational age

However, no such significant difference was found between PAPP-A MoM categories and preterm delivery, GDM, and gestational hypertension $(p=0.425$, 0.059 , and 0.65 , respectively).

Only preterm labor showed a significant linear trend for $\beta$-hCG MoM values ( $p=0.007$ ) (Table 5).

Table 5: The Linear Trend between Free $\beta$-hCG MoM and GDM, Preterm labor, and preterm birth

\begin{tabular}{|c|c|c|}
\hline $\begin{array}{l}\boldsymbol{\beta} \text {-hCG MoM } \\
\text { Categories } \\
\end{array}$ & $\begin{array}{l}\text { Number of patients with complication } \\
\text { in this category }(\%)\end{array}$ & $\begin{array}{l}\mathrm{p} \text {-value } \\
\text { for linear trend }\end{array}$ \\
\hline \multicolumn{3}{|c|}{ GDM } \\
\hline$\leq 0.26$ & $1 / 11(9.0)$ & \multirow{5}{*}{0.125} \\
\hline $0.26-0.40$ & $7 / 32(21.8)$ & \\
\hline $0.40-0.50$ & $7 / 48(14.5)$ & \\
\hline $0.50-0.70$ & $12 / 135(8.9)$ & \\
\hline$>0.70$ (control group) & $48 / 663(7.2)$ & \\
\hline \multicolumn{3}{|c|}{ Preterm labor } \\
\hline$\leq 0.26$ & $2 / 11(18.2)$ & \multirow{5}{*}{0.007} \\
\hline $0.26-0.40$ & $7 / 32(21.8)$ & \\
\hline $0.40-0.50$ & $7 / 48(14.5)$ & \\
\hline $0.50-0.70$ & $12 / 135(8.9)$ & \\
\hline$>0.70$ (control group) & $117 / 666(17.5)$ & \\
\hline \multicolumn{3}{|c|}{ Preterm birth } \\
\hline$\leq 0.26$ & $1 / 11(9)$ & \multirow{5}{*}{0.857} \\
\hline $0.26-0.40$ & $3 / 32(9.3)$ & \\
\hline $0.40-0.50$ & $4 / 48(8.3)$ & \\
\hline $0.50-0.70$ & $10 / 135(7.4)$ & \\
\hline$>0.70$ (control group) & $48 / 663(7.4)$ & \\
\hline
\end{tabular}

Bold numbers indicate statistically significant values $(p<0.05)$.

GDM: gestational diabetes mellitus, $\beta$-hCG: beta human chorionic gonadotropin, MoM: multiple of median

However, this significance was not detected when $\beta$-hCG MoM values were categorized as $\leq 0.40$ (5th percentile), >2.9 (95th percentile), and 0.75-1.49 (25th -75 th $)(p=0.47)$. The correlation coefficient of birth weight and PAPP-A MoM was 0.133 , which is negligible with a p-value of 0.0001 (Table 6).
Table 6: The correlation between PAPP-A MoM and birth weight

\begin{tabular}{|l|l|l|l|}
\hline \multicolumn{2}{|l|}{} & PAPP-A MoM & Birth Weight \\
\hline PAPP-A MoM & Pearson Correlation & 1 &, 133 \\
\hline & Significance (2-tailed) & &, 000 \\
\hline Birth Weight & Pearson Correlation &, 133 & 1 \\
\hline & Significance (2-tailed) &, 000 & \\
\hline
\end{tabular}

MoM: multiple of median, PAPP-A: pregnancy associated plasma protein-A

\section{Supplementary Table 1:}

\begin{tabular}{|l|l|l|}
\hline Percentile & free $\beta$-hCG MoM & PAPP-A MoM \\
\hline 1 & 0,26 & 0,26 \\
\hline 3 & 0,35 & 0,35 \\
\hline 5 & 0,40 & 0,42 \\
\hline 10 & 0,50 & 0,52 \\
\hline 25 & 0,70 & 0,73 \\
\hline 50 & 1 & 1,04 \\
\hline 75 & 1,49 & 1,47 \\
\hline 90 & 2,21 & 1,97 \\
\hline 95 & 2.9 & 2.5 \\
\hline
\end{tabular}

$\beta$-hCG: beta human chorionic gonadotropin, MoM: multiple of median, PAPP-A: pregnancy associated plasma protein-A Serum free $\beta$-hCG MoM and PAPP-A MoM values and their percentile equivalent

Serum free $\beta$-hCG MoM and PAPP-A MoM values and their percentile equivalent

\section{DISCUSSION}

Our data support that abnormal first-trimester PAPP-A and $\beta$-hCG levels were associated with some adverse pregnancy outcomes. Society of Obstetricians and Gynecologists of Canada Genetics Committee recommended using normal ranges as 0.4-2.5 MoM for PAPP-A and 0.5-3.0 MoM for $\beta$-hCG, where our data also met these levels at fifth and 95th percentile (Supplementary Table 1) (30).

Low PAPP-A levels, as a chorionic molecule, was reported to be associated with several obstetric complications in the literature such as IUGR and preterm labor (31). Several studies addressed the relationship between low birth weight and low levels of PAPP-A $(32,33)$. PAPP-A was shown to play an essential role in IUGR, and the severity of growth restriction was found to have a linear relationship with the decrease in PAPP-A levels (34). A recent case-control study, including 1070 pregnant women demonstrated the association between low serum PAPP-A levels and IUGR (17.4\% versus $1.2 \%, p<$ 0.001) (31). In our study, we found a significant association between first-trimester low PAPP-A level and preterm labor, SGA, LBW, IUEX, and IUGR development (Table 4).

There was a linear correlation between decreasing PAPP-A levels and complications presented with SGA and LBW (Table 3). Despite the studies supporting the association between birth weight and PAPP-A levels, Morssink et al. reported no significant association between PAPP-A and low birth weight (35). In our study, the correlation between birth weight and PAPP-A was weak ( $r=0.13, p=0.000$ ) (Table 6). Tarim et al. found no association between PAPP-A and macrosomia (36). However, Wells et al. reported an association between LGA and high PAPP-A levels in their study (37). Peterson et al. also demonstrated that PAPP-A levels of $>90 \%$ were associated with birthweight $>4500 \mathrm{~g}(\mathrm{p}=0.046)$ (38). Cignini et al. reported a significant increase of SGA and LGA with PAPP-A levels lower than the fifth percentile $(p<0.01)$ and higher than the 99th percentile $(p<0.01)$, respectively (39).

Several studies supported the association between low levels of PAPP-A in the first trimester and poor obstetric outcomes. Spencer et al. evaluated first-trimester PAPP-A levels of 54.722 singleton pregnancies (3). They showed that PAPP-A levels at the fifth percentile were associated with an 
almost three fold risk of IUEX (3). In our study, we compared PAPP-A levels at $<5$ th, 25-75th, and $>95$ th percentiles. The association between PAPP-A MoM levels $<5$ th percentile was found to be significant in IUEX ( $p<0.01)$ (Table 4).

There are conflicting data for the association of PAPP-A levels and preterm delivery $(15,40)$. In our study, preterm labor was associated with PAPP-A MoM levels lower than the fifth percentile $(p=0.002)$; however, there was no significant association between preterm delivery and PAPP-A levels $(p=0.425)$ (Table 5). Pummara et al. evaluated 3160 pregnant women for the assessment of the risk of preterm birth (41). They reported the rates of preterm delivery for $\leq 36$ weeks, $\leq 34$ weeks, and $\leq 32$ weeks of gestational age were significantly higher in women with PAPP-A levels $<10$ th percentile with a relative risk of $2.37,3.79$, and 5.41 , respectively when compared to women with normal PAPP-A levels (41). Although its predictive value is limited, numerous studies presented the association between low levels of PAPP-A in the first trimester and preterm birth $(42,43)$.

Dugoff et al. prospectively evaluated 34.271 pregnancies between 10 weeks 3 days and 13 weeks 6 days of gestation in the First and Second Trimester Evaluation of Risk (FASTER) trial (44). Women with PAPP-A level $\leq 5$ th percentile were found to experience adverse obstetric outcomes, such as IUEX, maternal hypertensive disorders, preterm delivery, premature rupture of membranes, and placental abruption more frequent than the rest of the pregnant population (44). The risk of preeclampsia was significantly higher with the PAPP-A levels $\leq 10$ th percentile (44). Smith et al. demonstrated a significantly increased risk for development of preeclampsia when PAPP-A levels are at the fifth percentile (OR:2.3) (45). However, Bersinger et al. reported increased serum PAPP-A levels in women with preeclampsia due to enhancement of the secretion of PAPP-A resulting from placental ischemia and insufficient placentation (46). The relationship between the high levels of PAPP-A and maternal hypertensive disorders are thought to be originated from the insufficient infiltration of trophoblasts (47). However, some studies revealed no relationship between low PAPP-A levels and preeclampsia (48, 49). Although the results of the studies investigating the relationship between PAPP-A levels and preeclampsia are conflicting, a recent meta-analysis, including 175.000 pregnant women supported the studies defending the lower PAPP-A levels for the increased risk of preeclampsia (OR:1.94) (50).

In a study evaluating the association between PAPP-A levels and GDM development, GDM was found to be 1.85 times higher in the low PAPP-A group (51). Donavan et al. evaluated the first-trimester prenatal screening biomarkers and risk of GDM development in their systemic review and meta-analysis, including 13 studies (52). The results from this meta-analysis indicated that first-trimester PAPP-A levels were significantly higher among the women who developed GDM later in their pregnancy (52). Spencer et al. found that GDM was 4.8 fold higher among women with PAPP-A levels $>0.62 \mathrm{MoM}$ (53). In our study, there was no significant the relationship for GDM and gestational hypertension rates with PAPP-A MoM levels $<5$ th, 25th-75th, and $>95$ th percentiles (Table 5).

$\beta$-hCG is produced by syncytiotrophoblast to induce progesterone secretion from corpus luteum and well known to be a sensitive marker for the diagnosis of pregnancy (31). Although it is known to be a successful biomarker to detect fetal chromosomal anomalies and several gynecological malignancies, the predictive value of first-trimester $\beta$-hCG for adverse obstetric outcomes was also widely studied in the literature (31). In a study evaluating 5584 singleton pregnancies from the first trimester until the delivery, obstetric complications such as gestational hypertension, miscarriage, and IUGR were higher with a $\beta$-hCG level of $<10$ th percentile of the reference range (15). Another study including, 34.271 pregnant women, found a significant increase in abortion with extremely low $\beta$-hCG level (< 1st percentile) (44). Ong et al. evaluated
5584 patients with low $\beta$-hCG levels in the first trimester ( $<10$ th percentile) and demonstrated that abortion, gestational hypertension, IUGR, and GDM were more frequent in this group (15). Studies focusing on the value of low and high levels of $\beta$-hCG accept two different pathophysiologic mechanisms for obstetric outcomes. As a marker of placentation, low $\beta$-hCG might be a sign of defective placentation, which is usually the main problem in IUGR and maternal hypertensive disorders. Based on this, numerous studies defended their hypotheses and investigated the obstetric outcomes of the pregnancies with low levels of $\beta$-hCG $(15,44)$. Another approach to explain the mechanism is that the impaired placental perfusion and placental damage might cause overproduction of $\beta$-hCG; hence higher plasma levels of $\beta$-hCG, which might be associated with poor obstetric outcomes (54). Yliniemi et al. demonstrated the association between lower $\beta$-hCG levels and the risk of preeclampsia (55). A meta-analysis of nine studies showed that low levels of $\beta$-hCG were associated with the risk of developing GDM (52). A recent study concluded that lower $\beta$-hCG has a predictive value for preterm labor but not for other adverse obstetric outcomes (56). Ranta et al. evaluated the first-trimester $\beta$-hCG MoM and the risk of developing preeclampsia, preterm delivery, and SGA (7). $\beta$-hCG MoM levels of pregnant women with these three major obstetric outcomes were significantly lower than healthy control groups $(p=0.02)(7)$. However, we found no statistically significant difference between $<5$ th, 25 th-75th, and $>95$ th percentile of $\beta$-hCG MoM among pregnant women with and without adverse obstetric outcomes, such as SGA, LBW, IUEX, preterm labor, preterm delivery, GDM, GHT and IUGR ( $p=0.6,0.79,0.59,0.47$, $0.74,0.08,0.68$, and 0.5 , respectively). On the other hand, these results were significant for preterm labor $(p=0.007)$ when we evaluated the significance for linear trend (Table 5). Our study including 889 singleton pregnancies showed no association between the first-trimester $\beta$-hCG levels and adverse obstetric outcomes.

The strength of our study is its prospective design. Nevertheless, the main limitation of our study is that small sample size to conclude the ability to pre$\operatorname{dict} \beta$-hCG and PAPP-A for adverse pregnancy and also neonatal outcomes.

\section{CONCLUSION}

In conclusion, our study suggested the possibility of predicting the women with the risk of adverse obstetric and neonatal outcomes by using first-trimester screening biomarkers, namely maternal free $\beta$-hCG, and PAPP-A levels. However, trials with larger sample size evaluating the $\beta$-hCG and PAPP-A levels during first-trimester screening are required.

Acknowledgments: Authors would like to thank to the patients participated in the study.

Funding Statement: None

Disclosures: The authors report no conflicts of interest.

\section{REFERENCES}

1. Kane SC, Costa Fda S, Brennecke S. First trimester biomarkers in the prediction of later pregnancy complications. Biomed Res Int. 2014;2014:807196.

2. Pihl K, Sorensen TL, Norgaard-Pedersen B, Larsen SO, Nguyen $\mathrm{TH}$, Krebs L, et al. First-trimester combined screening for Down syndrome: prediction of low birth weight, small for gestational age and pre-term delivery in a cohort of non-selected women. Prenat Diagn. 2008;28(3):247-53.

3. Spencer CA, Allen VM, Flowerdew G, Dooley K, Dodds L. Low levels of maternal serum PAPP-A in early pregnancy and the risk of adverse 
outcomes. Prenat Diagn. 2008;28(11):1029-36.

4. Fox NS, Chasen ST. First trimester pregnancy associated plasma protein-A as a marker for poor pregnancy outcome in patients with early-onset fetal growth restriction. Prenat Diagn. 2009;29(13):1244-8.

5. Salvig JD, Kirkegaard I, Winding TN, Henriksen TB, Torring N, Uldbjerg N. Low PAPP-A in the first trimester is associated with reduced fetal growth rate prior to gestational week 20. Prenat Diagn. 2010;30(6):503-8.

6. Canini S, Prefumo F, Pastorino D, Crocetti L, Afflitto CG, Venturini $\mathrm{PL}$, et al. Association between birth weight and first-trimester free beta-human chorionic gonadotropin and pregnancy-associated plasma protein A. Fertil Steril. 2008;89(1):174-8.

7. Ranta JK, Raatikainen K, Romppanen J, Pulkki K, Heinonen S. Decreased PAPP-A is associated with preeclampsia, premature delivery and small for gestational age infants but not with placental abruption. Eur J Obstet Gynecol Reprod Biol. 2011;157(1):48-52.

8. Savvidou MD, Syngelaki A, Muhaisen M, Emelyanenko E, Nicolaides KH. First trimester maternal serum free beta-human chorionic gonadotropin and pregnancy-associated plasma protein $\mathrm{A}$ in pregnancies complicated by diabetes mellitus. BJOG. 2012;119(4):410-6.

9. Karamustafaoğlu Balcı B, Kalelioğlu IH, Kılıç Y, Has R, Ömer B. How to calculate median Pregnancy-Associated Plasma Protein-A values to predict preeclampsia? Do We Need a Newer Formula? Gynecol Obstet Reprod Med. 2016;22(3):135-8.

10. Costa MA. The endocrine function of human placenta: an overview. Reproductive biomedicine online. 2016;32(1):14-43.

11. Bowman CJ, Streck RD, Chapin RE. Maternal-placental insulin-like growth factor (IGF) signaling and its importance to normal embryo-fetal development. Birth Defects Res B Dev Reprod Toxicol. 2010;89(4):339-49.

12. Lawrence JB, Oxvig C, Overgaard MT, Sottrup-Jensen L, Gleich GJ, Hays LG, et al. The insulin-like growth factor (IGF)-dependent IGF binding protein-4 protease secreted by human fibroblasts is pregnancy-associated plasma protein-A. Proceedings of the National Academy of Sciences. 1999;96(6):3149-53.

13. Conover CA, Bale LK, Overgaard MT, Johnstone EW, Laursen UH, Füchtbauer E-M, et al. Metalloproteinase pregnancy-associated plasma protein $A$ is a critical growth regulatory factor during fetal development. Development. 2004;131(5):1187-94.

14. Stenman UH, Tiitinen A, Alfthan H, Valmu L. The classification, functions and clinical use of different isoforms of HCG. Hum Reprod Update. 2006;12(6):769-84.

15. Ong CY, Liao AW, Spencer K, Munim S, Nicolaides KH. First trimester maternal serum free beta human chorionic gonadotrophin and pregnancy associated plasma protein $\mathrm{A}$ as predictors of pregnancy complications. BJOG. 2000;107(10):1265-70.

16. Sharp AN, Alfirevic Z. First trimester screening can predict adverse pregnancy outcomes. Prenat Diagn. 2014;34(7):660-7.

17. Mouri M, Rupp TJ. Threatened Abortion Treasure Island (FL): StatPearls Publishing; 2020 [updated Updated 2020 Jul 14. Available from: https://www.ncbi.nlm.nih.gov/books/NBK430747/.

18. Cunningham FG, Leveno KJ, Bloom SL, Dashe JS, Hoffmann BL, Casey BM, et al. Williams Obstetrics. 25th ed. New York: McGraw-Hill Education; 2018.

19. Goldenberg RL, Culhane JF, lams JD, Romero R. Epidemiology and causes of preterm birth. Lancet. 2008;371(9606):75-84.
20. Gestational Hypertension and Preeclampsia: ACOG Practice Bulletin Summary, Number 222. Obstet Gynecol. 2020;135(6):1492-5.

21. American College of O, Gynecologists, Task Force on Hypertension in P. Hypertension in pregnancy. Report of the American College of Obstetricians and Gynecologists' Task Force on Hypertension in Pregnancy. Obstet Gynecol. 2013;122(5):1122-31.

22. American Diabetes A. Gestational diabetes mellitus. Diabetes Care. 2003;26 Suppl 1:S103-5.

23. Beloosesky R, Ross MG. Oligohydramnios: Etiology, diagnosis, and management. In: UpToDate, Post TW (Ed), UpToDate, Waltham, MA (Accessed on August 26, 2020).

24. Beloosesky R, Ross MG. Polyhydramnios: Etiology, diagnosis, and management

. In: UpToDate, Post TW (Ed), UpToDate, Waltham, MA (Accessed on August 26, 2020).

25. Battaglia FC, Lubchenco LO. A practical classification of newborn infants by weight and gestational age. J Pediatr. 1967;71(2):159-63.

26. Mandy GT. Infants with fetal (intrauterine) growth restriction. In: UpToDate, Post TW (Ed), UpToDate, Waltham, MA (Accessed on August 26, 2020).

27. Mandy GT. Large for gestational age newborn. In: UpToDate, Post TW (Ed), UpToDate, Waltham, MA (Accessed on August 26, 2020).

28. Abramowicz JS, Ahn JT. Fetal macrosomia. In: UpToDate, Post TW (Ed), UpToDate, Waltham, MA (Accessed on August 26, 2020).

29. Cleary-Goldman J, Robinson JN. Delivery of the low birth weight singleton fetus

. In: UpToDate, Post TW (Ed), UpToDate, Waltham, MA (Accessed on August 26, 2020).

30. Gagnon A, Wilson RD, Society Of O, Gynaecologists Of Canada Genetics C. Obstetrical complications associated with abnormal maternal serum markers analytes. J Obstet Gynaecol Can. 2008;30(10):918-32.

31. Ghasemi-Tehrani H, Sadeghian A, Entezari R. Relationship Between Pregnancy Complications and Serum Pregnancy Associated-Plasma-Protein-A and Free-beta-Human Chorionic Gonadotropin in the First Trimester Among Iranian Women. J Family Reprod Health. 2017;11(4):219-24.

32. Arai S, Arai C, Fujimaki M, Iwamoto Y, Kawarada M, Saito Y, et al. Cutaneous tumour-like lesions due to poxvirus infection in Chilean flamingos. J Comp Pathol. 1991;104(4):439-41.

33. Tul N, Pusenjak S, Osredkar J, Spencer K, Novak-Antolic Z. Predicting complications of pregnancy with first-trimester maternal serum free-betahCG, PAPP-A and inhibin-A. Prenat Diagn. 2003;23(12):990-6.

34. Cowans NJ, Spencer K. First-trimester ADAM12 and PAPP-A as markers for intrauterine fetal growth restriction through their roles in the insulin-like growth factor system. Prenat Diagn. 2007;27(3):264-71.

35. Morssink LP, Kornman LH, Hallahan TW, Kloosterman MD, Beekhuis JR, de Wolf BT, et al. Maternal serum levels of free beta-hCG and PAPP-A in the first trimester of pregnancy are not associated with subsequent fetal growth retardation or preterm delivery. Prenat Diagn. 1998;18(2):147-52. 36. Tarim E, HACIVELIOĞLU SÖ, Cok T, BAĞIŞ HT. First trimester maternal serum PAPP-A levels and macrosomia in nondiabetic mothers. Turkish Journal of Medical Sciences. 2011;41(4):581-6.

37. Wells G, Bleicher K, Han X, McShane M, Chan YF, Bartlett A, et al. Maternal Diabetes, Large-for-Gestational-Age Births, and First Trimester Pregnancy-Associated Plasma Protein-A. J Clin Endocrinol Metab. 
2015;100(6):2372-9.

38. Peterson SE, Simhan HN. First-trimester pregnancy-associated plasma protein $A$ and subsequent abnormalities of fetal growth. Am J Obstet Gynecol. 2008;198(5):e43-5.

39. Cignini P, Maggio Savasta L, Gulino FA, Vitale SG, Mangiafico L, Mesoraca $A$, et al. Predictive value of pregnancy-associated plasma protein-A (PAPP-A) and free beta-hCG on fetal growth restriction: results of a prospective study. Arch Gynecol Obstet. 2016;293(6):1227-33.

40. Patil M, Panchanadikar TM, Wagh G. Variation of papp-a level in the first trimester of pregnancy and its clinical outcome. J Obstet Gynaecol India. 2014;64(2):116-9.

41. Pummara P, Tongsong T, Wanapirak C, Sirichotiyakul S, Luewan S. Association of first-trimester pregnancy-associated plasma protein A levels and idiopathic preterm delivery: A population-based screening study. Taiwan J Obstet Gynecol. 2016;55(1):72-5.

42. Goetzinger KR, Cahill AG, Macones GA, Odibo AO. Association of first-trimester low PAPP-A levels with preterm birth. Prenat Diagn. 2010;30(4):309-13.

43. Livrinova V, Petrov I, Samardziski I, Jovanovska V, Boshku AA, Todorovska I, et al. Clinical Importance of Low Level of PAPP-A in First Trimester of Pregnancy - An Obstetrical Dilemma in Chromosomally Normal Fetus. Open Access Maced J Med Sci. 2019;7(9):1475-9.

44. Dugoff L, Hobbins JC, Malone FD, Porter TF, Luthy D, Comstock $\mathrm{CH}$, et al. First-trimester maternal serum PAPP-A and free-beta subunit human chorionic gonadotropin concentrations and nuchal translucency are associated with obstetric complications: a population-based screening study (the FASTER Trial). Am J Obstet Gynecol. 2004;191(4):1446-51.

45. Smith GC, Stenhouse EJ, Crossley JA, Aitken DA, Cameron AD, Connor JM. Early pregnancy levels of pregnancy-associated plasma protein $a$ and the risk of intrauterine growth restriction, premature birth, preeclampsia, and stillbirth. J Clin Endocrinol Metab. 2002;87(4):1762-7.

46. Bersinger NA, Smarason AK, Muttukrishna S, Groome NP, Redman $C W$. Women with preeclampsia have increased serum levels of pregnancy-associated plasma protein A (PAPP-A), inhibin A, activin A and soluble E-selectin. Hypertens Pregnancy. 2003;22(1):45-55.

47. Zhang Z, Xu H, Liu X, Li P, Du W, Han Q. Association of pregnancy-associated plasma protein $A$ and vascular endothelial growth factor with pregnancy-induced hypertension. Experimental and therapeutic medicine. 2019;18(3):1761-7.
48. Karahasanovic A, Sorensen S, Nilas L. First trimester pregnancy-associated plasma protein $\mathrm{A}$ and human chorionic gonadotropin-beta in early and late pre-eclampsia. Clin Chem Lab Med. 2014;52(4):521-5.

49. Gupta S, Goyal M, Verma D, Sharma A, Bharadwaj N, Kabra $M$, et al. Adverse pregnancy outcome in patients with low pregnancy-associated plasma protein-A: The Indian Experience. J Obstet Gynaecol Res. 2015;41(7):1003-8.

50. Morris RK, Bilagi A, Devani P, Kilby MD. Association of serum PAPP-A levels in first trimester with small for gestational age and adverse pregnancy outcomes: systematic review and meta-analysis. Prenat Diagn. 2017;37(3):253-65.

51. Ramezani S, Ahmadi Doulabi M, Saqhafi H, Alipoor M. Prediction of Gestational Diabetes by Measuring the Levels of Pregnancy Associated Plasma Protein-A (PAPP-A) During Gestation Weeks 11-14. Journal of Reproduction \& Infertility. 2020;21(2):130-7.

52. Donovan BM, Nidey NL, Jasper EA, Robinson JG, Bao W, Saftlas AF, et al. First trimester prenatal screening biomarkers and gestational diabetes mellitus: A systematic review and meta-analysis. PLoS One. 2018;13(7):e0201319.

53. Spencer K, Cowans NJ. The association between gestational diabetes mellitus and first trimester aneuploidy screening markers. Ann Clin Biochem. 2013;50(Pt 6):603-10.

54. Ozdamar O, Gun I, Keskin U, Kocak N, Mungen E. The role of maternal serumbeta-HCG and PAPP-A levels at gestational weeks 10 to 14 in the prediction of pre-eclampsia. Pak J Med Sci. 2014;30(3):568-73.

55. Yliniemi A, Makikallio K, Korpimaki T, Kouru H, Marttala J, Ryynanen M. Combination of PAPPA, fhCGbeta, AFP, PIGF, sTNFR1, and Maternal Characteristics in Prediction of Early-onset Preeclampsia. Clin Med Insights Reprod Health. 2015;9:13-20.

56. Pakniat H, Bahman A, Ansari I. The Relationship of Pregnancy-Associated Plasma Protein A and Human Chorionic Gonadotropin with Adverse Pregnancy Outcomes: A Prospective Study. J Obstet Gynaecol India. 2019;69(5):412-9. 